\title{
The latest Post-Variscan fluids in the Spanish Central System: evidence from fluid inclusion and stable isotope data
}

\author{
Tomás Martín Crespo ${ }^{\mathrm{a}, *}$, Antonio Delgado ${ }^{\mathrm{b}, 1}$, Elena Vindel Catena ${ }^{\mathrm{a}}$, \\ José Angel López García ${ }^{a}$, Cécile Fabre \\ ${ }^{a}$ Departamento de Cristalografía y Mineralogía, Facultad de Ciencias Geológicas, Complutense University, 28040 Madrid, Spain \\ ${ }^{\mathrm{b}}$ Departamento de Ciencias de la Tierra y Química Ambiental, Estación Experimental del Zaidín (CSIC), 18008 Granada, Spain \\ ${ }^{\circ}$ CREGU-G2R, BP 23, 54501 Vandeouvre les Nancy, France
}

\begin{abstract}
The Spanish Central System has been subjected to repeated fluid incursions, which were responsible for a variety of mineralizing episodes including $\mathrm{W}-\mathrm{Sn}, \mathrm{Cu}-\mathrm{Zn}-\mathrm{Pb}-\mathrm{As}-(\mathrm{Ag}), \mathrm{F}-\mathrm{Ba}$ and barren quartz veins. These hydrothermal fluids occurred over a $200 \mathrm{Ma}$ time period and the latest hydrothermal event is recorded in barren quartz veins. This study is a multidisciplinary approach leading to the characterization of the hydrothermal fluids preserved in barren quartz veins, which are spatially but not temporally related to Hercynian upper crustal granites. The veins were dated by the ${ }^{39} \mathrm{Ar} /{ }^{40} \mathrm{Ar}$ method, and the fluids were examined using petrographic, microthermometric, chemical and isotopic methods. Fluid inclusions in barren quartz veins indicate that two fluids were related to this hydrothermal event. The main part of the quartz veins were formed from an early low salinity $(<1 \mathrm{wt} \% \mathrm{NaCl}) \mathrm{H}_{2} \mathrm{O}-\mathrm{NaCl}$ fluid. This fluid was trapped at around $270 \pm 25^{\circ} \mathrm{C}$ and $0.1-1 \mathrm{kbar}$ under sublithostatic to hydrostatic conditions. $\delta^{18} \mathrm{O}(-9$ to $2 \%$ ) and $\delta \mathrm{D}(-70$ to $-34.5 \%$ ) values indicate a meteoric origin for water, with significant water/rock interactions. The latest $\mathrm{H}_{2} \mathrm{O}-\mathrm{NaCl}-\mathrm{CaCl}_{2}$ fluid is found in two types of fluid inclusions: a primary liquid-vapour type (16-24 wt $\% \mathrm{NaCl}$ and $1-12 \mathrm{wt} \% \mathrm{CaCl}_{2}$ ) and secondary hypersaline type (7-15 wt $\% \mathrm{NaCl}$ and $21-27 \mathrm{wt} \% \mathrm{CaCl}_{2}$ ). Significant $\mathrm{Li}$ concentrations in this fluid were confirmed. This late Ca-bearing fluid formed quartz crystals in the central part of the veins, and was trapped at 70$140{ }^{\circ} \mathrm{C}$, at a maximum pressure of $0.5 \mathrm{kbar}$. The low $\delta^{18} \mathrm{O}(-20$ to $-6 \%$ ) and $\delta \mathrm{D}(-137$ to $-116 \%$ ) values suggest a meteoric origin for this fluid, however its high salinity probably requires a source from Triassic evaporite basins located in the NE tip of the Spanish Central System. Anomalously low isotopic values have been previously reported from kaolinites of Lower Cretaceous age. Anomalous climatic conditions during the Cretaceous appear to be the main reason to explain this very negative meteoric water. Strong isotopic depletion in meteoric water has been observed in modern areas with monsoonal climates. The hydrothermal evolution of barren quartz veins in the Spanish Central System is comparable to other hydrothermal Post-Variscan events in central and south-western Europe related to the opening of the NorthAtlantic during Cretaceous time.
\end{abstract}

Keywords: Fluid inclusions; Stable isotopes; Hydrothermal fluids; Post-Variscan; Spanish Central System

\section{Introduction}

The Spanish Central System has been subjected to repeated fluid incursions, which are responsible for different types of granite-hosted and metamorphic-hosted mineralization: $\mathrm{W}-\mathrm{Sn}, \mathrm{Cu}-\mathrm{Zn}-\mathrm{Pb}-\mathrm{As}(\mathrm{Ag})$ sulphides, $\mathrm{F}-\mathrm{Ba}$ and barren quartz veins. Thus, the Spanish Central System offers a good opportunity to analyse a variety of hydrothemal fluids, which may be compared to other hydrothermal

\footnotetext{
* Corresponding author. Fax: +34-91-394-48-72.

E-mail addresses: tmartin@geo.ucm.es (T. Martín Crespo), antode1@eez.csic.es (A. Delgado), evindel@geo.ucm.es (E. Vindel Catena), jangel@geo.ucm.es (J.A. López García).

${ }^{1}$ Fax: +34-95-812-96-00
}

Post-Variscan events in Europe. These hydrothermal fluids span a time interval of around $200 \mathrm{Ma}$. Fluids trapped in the barren quartz veins represent the latest hydrothermal event (Caballero et al., 1992; Tornos, Delgado, Casquet, \& Galindo, 2000; Vindel, Lopez, Martín Crespo, \& García, 2000). Tungsten base-metal transport were related to aqueous-carbonic fluids (García, Vindel, \& López García, 1999a,b; Vindel, Lopez, Boiron, Cathelineau, \& Prieto, 1995), fluorite-barite ores to aqueous fluids (Galindo, Tornos, Darbyshire, \& Casquet, 1994; Tornos, Casquet, Locutura, \& Collado, 1991) and later barren quartz veins to $\mathrm{CaCl}_{2}$ brines (Martín Crespo, López García, Banks, Vindel, \& García, 1999). This study encompasses for the first time the whole evolution of hydrothermal events. Cabearing fluids have not been previously clearly defined in 
the Spanish Central System, and could be compared to the Ca-rich brines found in other Post-Variscan hydrothermal mineralizations in Europe (Behr \& Gerler, 1987; Behr, Horn, Frentzel-Beyme, \& Reutel, 1987; Canals \& Cardellach, 1993; Charef \& Sheppard, 1988; Lodemann et al., 1998; Muchez \& Sintubin, 1998; Muchez, Slobodnik, Viaene, \& Keppens, 1995; Munoz, Boyce, Courjault-Rade, Fallick, \& Tollon, 1994, 1999; O'Connor, Högelsberger, Feely, \& Rex, 1993; O'Reilly, Jenkin, Feely, Alderton, \& Fallick, 1997; Wilkinson, Jenkin, Fallick, \& Foster, 1995). Fluid migration during Mesozoic time in the Spanish Central System comprise a flow system involving meteoric waters that increased in salinity because of interaction with evaporitic-bearing sequences.

\section{Geological setting}

The Spanish Central System is a northeast trending mountain range located in the inner zone of the Hercynian Belt of Spain. Its central part, the so-called 'Sierra de Guadarrama', consists of granitoids and high to medium grade metamorphic rocks, mostly pre-Hercynian orthogneisses and some pre-Ordovician metasedimentary rocks. Scattered relicts of small Permian detrital basins, and of a Triassic and Jurassic cover, are also preserved in the northeast of the Spanish Central System. Late Hercynian granitoids were emplaced from 345 to $285 \mathrm{Ma}$ (Casillas, Vialette, Peinado, Duthou, \& Pin, 1991; Ibarrola et al., 1987; Pérez del Villar, Crespo, Pardillo, Pelayo, \& Galán, 1996a; Pérez del Villar et al., 1996b; Vialette, Bellido, Fúster, \& Ibarrola, 1981; Villaseca, Eugercios, Snelling, Huertas, \& Castellón, 1995) after the main Hercynian orogeny. The granitoids are mostly peraluminous monzogranites and leucogranites, with minor intrusions of more mafic composition. The main groups of granitoids generate typical contact aureoles in the surrounding wall rocks indicating a high emplacement level, between 5 and $8 \mathrm{~km}$ depth (Villaseca, Barbero, \& Rodgers, 1998). The Sierra de Guadarrama has experienced numerous fluid-rock interaction events. Mineralization is of minor economic importance, although a large number of mineralised veins accompanied by hydrothemal alteration occur throughout the batholith and country rocks (Vindel et al., 1995). The oldest hydrothermal event (300-290 Ma) was associated with veins containing wolframite and sulphides in greisenized granites, whereas barren quartz veins are the most recent event. An age of $100.6 \pm 4.3 \mathrm{Ma}$ was obtained from a granite-hosted barren quartz vein by $\mathrm{K}$-Ar dating of sericite from phyllic alteration (Caballero et al., 1992).

\section{Barren quartz veins}

A large number of veins have been identified throughout the granitic (Colmenarejo, Cerceda, Manzanares el Real, La Cabrera) and metamorphic outcrops (Colmenarejo, Colmenar
Viejo) of Sierra de Guadarrama (Fig. 1). Their essential features are given in Table 1.

\subsection{Granite-hosted barren quartz veins}

These veins range in thickness from 0.3 to $5 \mathrm{~m}$, have strike lengths of up to $2 \mathrm{~km}$ and have subvertical dips. The two most frequent strike directions are $\mathrm{N} 20^{\circ} \mathrm{E}$ and $\mathrm{N} 110^{\circ} \mathrm{E}$, which follow the main extensional directions between Lower and Upper Cretaceous cover (Alonso \& Mas, 1982).

Host rock features and the main characteristics of the veins are outlined below:

Colmenarejo (COL): barren quartz veins crosscut the Zarzalejo-Valdemorillo biotitic monzogranite. The texture of this granite is typically hypidiomorphic and equigranular, however, a porphyritic facies with a medium-grained matrix has also been observed. The veins are located in the SE of the area and comprise a group of $10 \mathrm{~N} 20^{\circ} \mathrm{E}$ veins. Several later fractures striking $\mathrm{E}-\mathrm{W}$ have affected the quartz veins.

Cerceda (CER): veins occur throughout two granite types, a fine-grained leucogranite and a porphyritic coarse-grained monzogranite (El Cardín type; Villaseca et al., 1998). Four quartz veins have been recognised along the contact between the two granites, which display a predominantly strike $\mathrm{N}-\mathrm{S}$.

The Manzanares el Real (MAN) quartz vein also crosscuts the El Cardín granite (Villaseca et al., 1998). A single $\mathrm{N} 116^{\circ} \mathrm{E}$ barren quartz vein has been recognised in this area.

The La Cabrera (CAB) massif represents the eastern-most granitic intrusion in the Spanish Central System. It comprises of several varieties of granite. The main facies comprises medium to coarse-grained biotitic granites and monzogranites with subordinate porphyritic varieties. Medium to fine-grained, biotitic, highly evolved leucogranites are related to this main facies (Bellido et al., 1981). The studied quartz vein occur in the biotitic granite, striking $\mathrm{N} 20^{\circ} \mathrm{E}$, and is located in the $\mathrm{SW}$ part of the batholith.

Three morphological and textural types of quartz can be distinguished in most of the veins: (1) massive quartz (QI) at the vein margins. Suitable fluid inclusions for microthermometric analyses $(>5 \mu \mathrm{m})$ are not recognised in this type of quartz; (2) central part of clear quartz crystals (QII) located in the centre of the veins, and (3) margin of QII crystal (QII). Both QII and QIII appear in vug cavities and contain abundant fluid inclusions. Hydrothermal muscovite, minor amounts of fluorite and iron oxides have been recognised between quartz crystals (Table 1).

Hydrothermal alteration is restricted to the proximity of the lodes (around $0.5 \mathrm{~m}$ width), and is poorly developed. Muscovitization and chloritization are the usual and most 


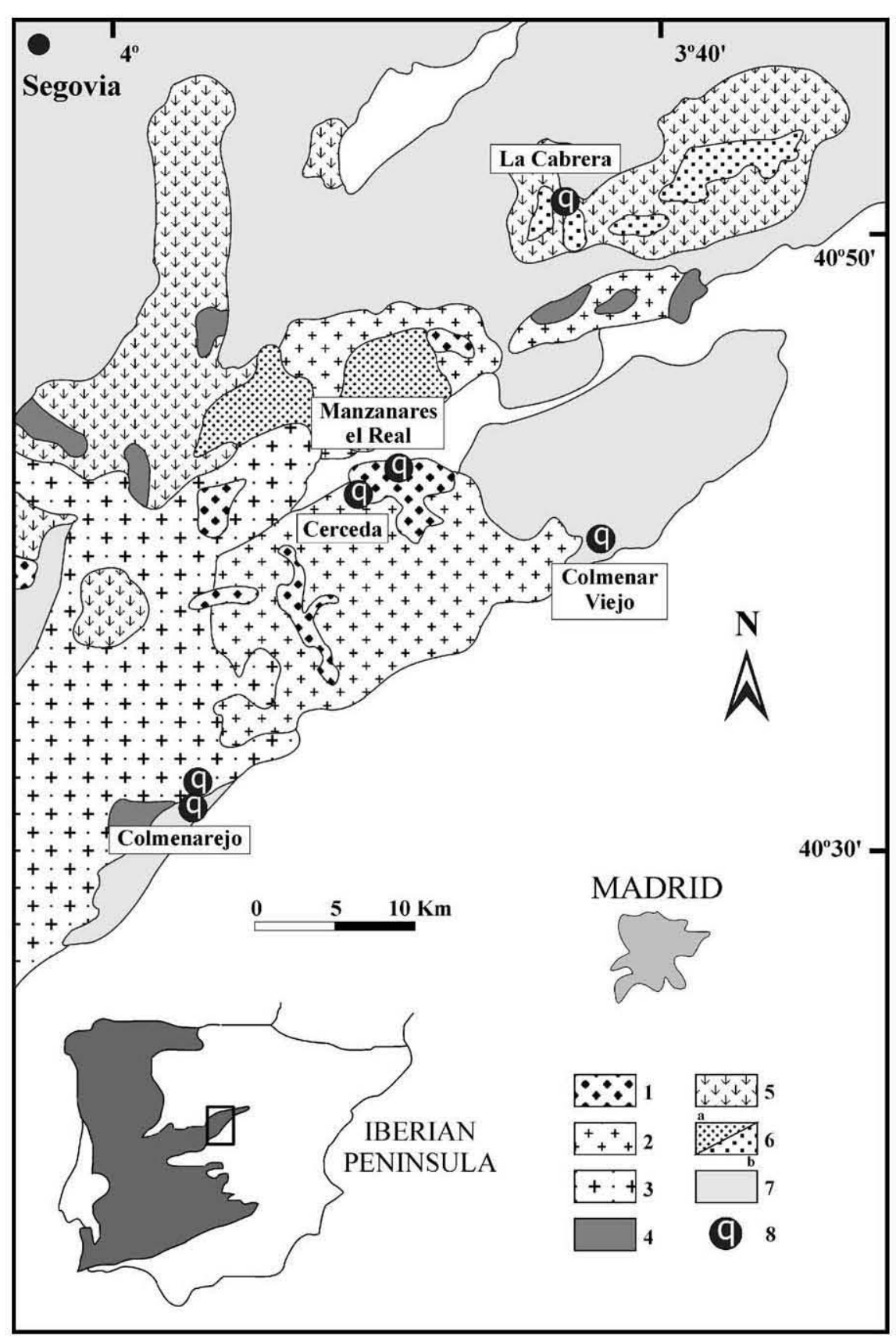

Fig. 1. Simplified map of the studied area showing the barren quartz vein locations. Legend: (1) leucogranite, (2) coarse-grained monzogranite, (3) porphyritic monzogranite, (4) not assigned granite, (5) monzogranite, (6a) coarse-grained leucogranite, (6b) leucogranite, (7) metamorphic rock, (8) barren quartz vein (after Villaseca et al., 1998).

important alterations. Muscovitization is generated by alteration of feldspars, while chloritization is restricted to the alteration of biotites within the granites.

\subsection{Gneiss-hosted barren quartz veins}

Gneiss-hosted quartz veins (Colmenarejo and Colmenar Viejo) crosscut pre-Hercynian augen orthogneisses. They show a similar structural setting, paragenesis and wallrock alteration to the granite-hosted veins. At Colmenarejo, the $\mathrm{N} 20^{\circ} \mathrm{E}$ veins cut both a monzogranite and a augen orthogneiss. Brecciation of wallrock and veins is characteristic, showing typically massive veins and crosscutting microveins, like stockworks. Brecciated fragments of wall-rock occur in several veins. Only QI and QII quartz types are recognised in these veins. Hydrothermal alteration is restricted to a narrow zone $(\sim 10 \mathrm{~cm})$ adjacent to the veins and is characterised by muscovitization of feldspars. Five barren quartz veins striking $\mathrm{N} 20-40^{\circ} \mathrm{E}$ have been studied at Colmenar Viejo. Silicification and muscovitization were recognised as hydrothermal alterations. 


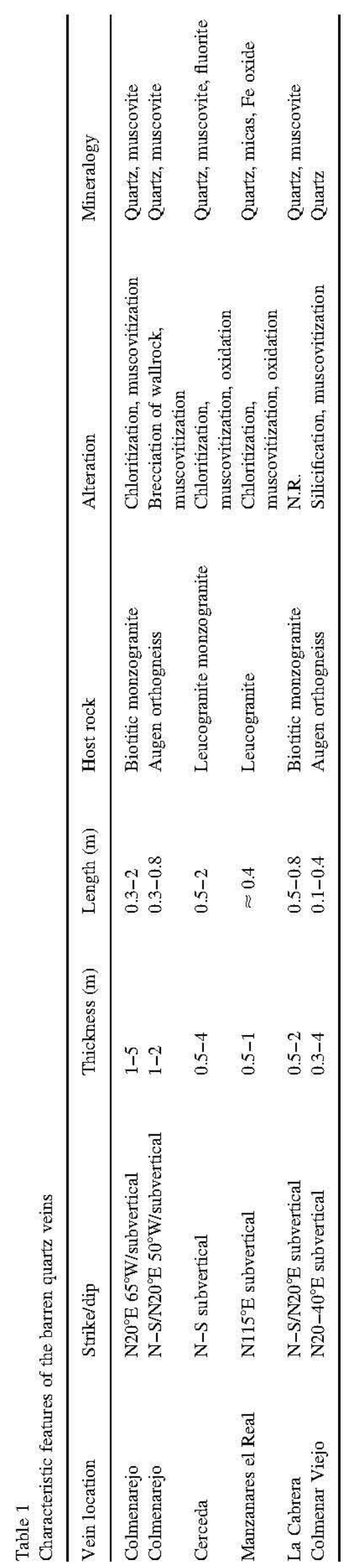

\section{Analytical methods}

A microthermometric study ( $\sim 1000$ inclusions from 44 samples) was carried out on doubly polished wafers ( $<300 \mu \mathrm{m}$ in thickness) using a Linkam THMSG 600 heating-freezing stage (MacDonald \& Spooner, 1981). The stage was calibrated with melting-point of solid standards at $T>25^{\circ} \mathrm{C}$, and natural and synthetic inclusions at $T<0^{\circ} \mathrm{C}$. The rate of heating was monitored in order to get an accuracy of $\pm 0.2^{\circ} \mathrm{C}$ during freezing, $\pm 1{ }^{\circ} \mathrm{C}$ when heating over the $25-400^{\circ} \mathrm{C}$ range, and $\pm 4{ }^{\circ} \mathrm{C}$ over the $400-$ $600^{\circ} \mathrm{C}$ range. Salinity of $\mathrm{H}_{2} \mathrm{O}-\mathrm{NaCl}$ inclusions, expressed as equivalent weight percent $\mathrm{NaCl}$, was calculated from microthermometric data using equations from Bodnar (1993). Salinity and composition of $\mathrm{H}_{2} \mathrm{O}-\mathrm{NaCl}-\mathrm{CaCl}_{2}$ inclusions was established from ice, hydrohalite and halite melting temperatures using a Microsoft Excel Add-in developed by J. Naden (Naden, 1996).

$P-T$ properties for the $\mathrm{H}_{2} \mathrm{O}-\mathrm{NaCl}-\mathrm{CaCl}_{2}$ system are not available, but data from Zhang and Frantz (1987) for the $\mathrm{H}_{2} \mathrm{O}-\mathrm{NaCl}$ system can be used to approximate the inclusion isochores.

Determination of ion ratios in individual fluid inclusions was done by Laser Induced Breakdown Spectroscopy (LIBS), coupling laser ablation with an optical emission spectrometer at CREGU, Nancy. Recent developments using LIBS, previously described by Boiron et al. (1991, 1997), Fabre, Boiron, Dubessy, and Moissette (1999) and Moissette et al. (1997), have shown that this method can be adapted for the analysis of the ion content in individual fluid inclusions. A $5 \mathrm{~ns}$ laser pulse is delivered by a Nd-YAG laser $(266 \mathrm{~nm})$ and focused onto the sample through a Cassegrain objective. A plasma is created by the interaction of the laser and matter. Emission lines of elements present in the plasma are directly analysed by an optical emission spectrometer equipped with a pulsed and gated multichannel detector. The intensity of the emission lines is proportional to the concentration of the elements. The repeatability of LIBS for net intensity ratios is around 10 and $20 \%$ for glasses and fluid inclusions, respectively (Fabre et al., 1999). Such results are quite acceptable for the validation of the analytical data. The detection limits are calculated for major elements in fluid inclusions and are for $\mathrm{Na}$ and $\mathrm{Li}$ $10 \mathrm{ppm}$, Ca 20 ppm and $\mathrm{K} 750 \mathrm{ppm}$. These detection limits are those required for the determination of ions in a majority of fluid inclusions.

Bulk crush-leach analysis was performed on samples (between 0.5 and $1 \mathrm{~g}$ ) prepared and analysed using the procedures set out in Bottrell, Yardley, and Buckley (1988), and modified by Yardley, Banks, Bottrell, and Diamond (1993). The anions $\mathrm{Cl}$ and $\mathrm{Br}$ were analysed by ion chromatography on double distilled water leaches using a Dionex 4500I HPLC. Na was determined on the same solution leached with an acidified $\mathrm{LaCl}_{3}$ solution by Flame Emission Spectroscopy (FES).

Irradiation and stepwise heating of micas was done 
according to Kamber, >Blenkinsop, Villa, and Dahl (1995). $10 \mathrm{mg}$ of mica were handpicked to achieve visual purity of $\sim 100 \%$. The selected sample was irradiated in the Ris $\varnothing$ reactor (Denmark), and step-heated in a double-vacuum resistance oven connected to a MAP 215-50B mass spectrometer. The analyses were carried out at the Mineralogisches Institut, Bern (Switzerland).

Thermal decrepitation was chosen as the method for extracting fluid inclusions from quartz for the hydrogen isotope analyses. Values of $\delta \mathrm{D}_{\text {fuid }}$ were determined using the uranium technique, with a similar methodology to that described by Godfrey (1962). Samples were degassed overnight by heating at $70^{\circ} \mathrm{C}$ under high vacuum. The platinum crucible was then heated (by a radio-frequency induction furnace) to approximately $1200{ }^{\circ} \mathrm{C}$. The released water was converted to hydrogen by passing over uranium metal at about $800^{\circ} \mathrm{C} . \delta \mathrm{O}^{18}$ was determined in quartz $(10-15 \mathrm{mg})$ reacting with a stoichiometric excess of $\mathrm{ClF}_{3}$ at $650{ }^{\circ} \mathrm{C}$ for $12 \mathrm{~h}$ (Borthwick \& Harmon, 1982; Vennemann \& Smith, 1990). Released oxygen was converted to $\mathrm{CO}_{2}$ by reaction with a hot platinized graphite rod (Clayton \& Mayeda, 1963). The isotope ratios were measured in a Finnigan MAT 251 mass spectrometer. Commercial $\mathrm{CO}_{2}$ was used as the internal standard for the oxygen analyses of silicates contrasted with the V-SMOW, SLAP and GIPS water standards, giving a value of $\delta^{18} \mathrm{O}=+9.6 \pm 0.15 \%$ o (V-SMOW) for the international NBS-28 (quartz) standard. The analyses were carried out using a Finnigan MAT 251 spectrometer at the Stable Isotope Laboratory, Estación Experimental del Zaidín (Granada, Spain).

\section{Fluid inclusion data}

\subsection{Fluid inclusion petrography and chronology}

Three types of fluid inclusion were identified in the quartz veins. They are all aqueous and no $\mathrm{C}-\mathrm{N}-\mathrm{S}$ species were detected by micro-Raman analysis (at G2R, Nancy, France). Notation of the fluid inclusion types follows the nomenclature of Boiron, Essarraj, Sellier, Cathelineau, Lespinasse, and Poty (1992), which takes into account the nature of the dominant chemical phases and the type of phase change. The relative chronology of the fluid inclusions is deduced from textural observations.

$L w 1$ : idiomorphic inclusions (liquid + vapour) have been located as primary in the centre of the quartz crystals (QII) following growth planes parallel to the crystal faces (Fig. 2a). Some irregular inclusions have been recognised as pseudosecondary in fluid inclusion planes which
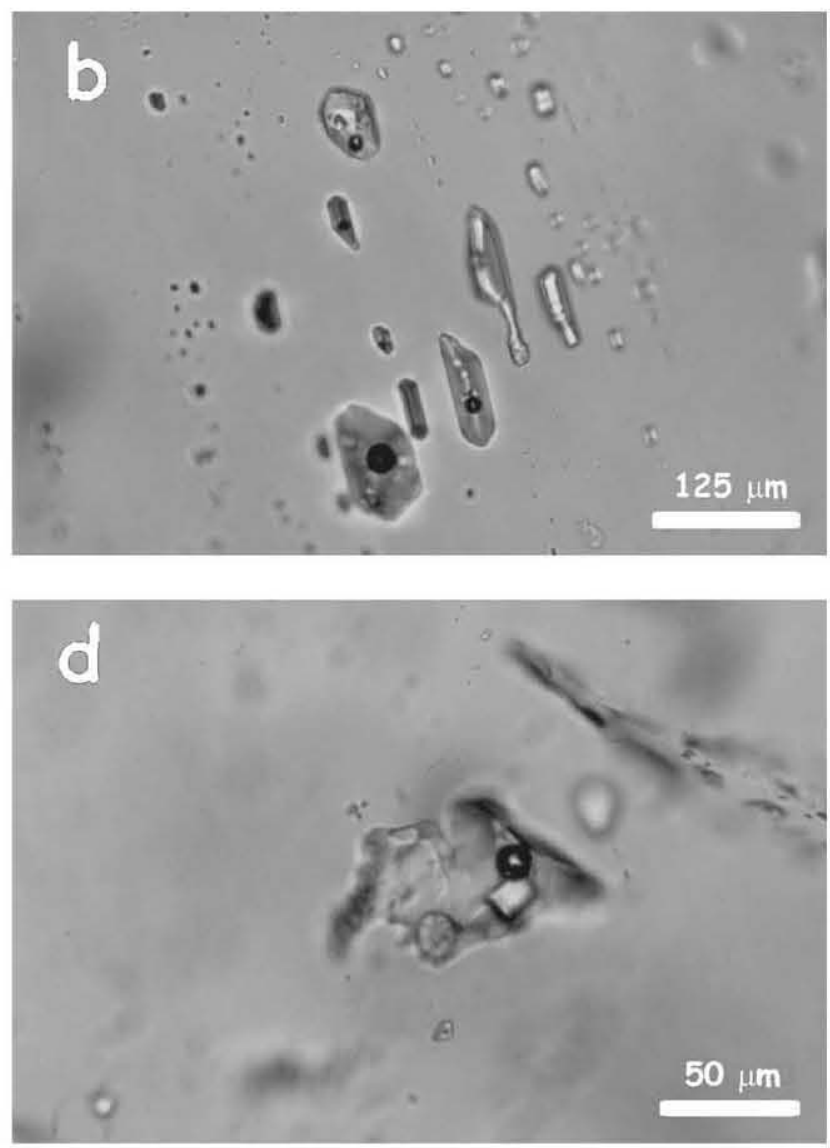

Fig. 2. (a) Primary Lw1 fluid inclusions following growth planes. (b) Primary Lw 2 fluid inclusions. (c) Secondary Lw2 inclusions scattered along healed fractures. (d) Lw-h fluid inclusion showing a daughter cubic crystal (halite) and lamellar muscovite as trapped mineral. 


\section{Table 2}

Fluid inclusion microthermometric data for barren quartz veins summarised by their host rock (granites and augen gneisses) ( $T_{\mathrm{FM}}$ : first ice melting; $T_{\mathrm{HH}}$ : last hidrohalite melting; $T_{\mathrm{MCE}}$ : last ice melting; $T_{\mathrm{S}}$ : last solid melting; $T_{\mathrm{H}}$ : homogenization to liquid; [2]= number of samples; (970) = number of measurements)

\begin{tabular}{|c|c|c|c|c|}
\hline Host rock & Granites & & & Augen gneisses \\
\hline Locality & $\begin{array}{l}\text { Colmenarejo [12], } \\
\text { Cerceda [10], La } \\
\text { Cabrera [4], } \\
\text { Manzanares El Real [8] }\end{array}$ & & & $\begin{array}{l}\text { Colmenarejo [7], } \\
\text { Colmenar Viejo }[3]\end{array}$ \\
\hline Inclusion type & Lw1 & Lw2 & Lw-h & Lw1 \\
\hline Components & $\mathrm{H}_{2} \mathrm{O}-\mathrm{NaCl}$ & $\mathrm{H}_{2} \mathrm{O}-\mathrm{NaCl}-\mathrm{CaCl}_{2}$ & $\mathrm{H}_{2} \mathrm{O}-\mathrm{CaCl}_{2}-\mathrm{NaCl}$ & $\mathrm{H}_{2} \mathrm{O}-\mathrm{NaCl}$ \\
\hline Phases at room temperature & Two phases & Two phases & Three phases & Two phases \\
\hline \% Vapour & $5-30$ & $5-10$ & $5-10$ & $10-20$ \\
\hline$T_{\mathrm{FM}}\left({ }^{\circ} \mathrm{C}\right)(30)$ & - & $-67 /-55$, mode: -61 & - & - \\
\hline$T_{\mathrm{HH}}\left({ }^{\circ} \mathrm{C}\right)(215)$ & - & $-18.2 /-2$, mode: -8 & - & - \\
\hline$T_{\text {MCE }}\left({ }^{\circ} \mathrm{C}\right)(970)$ & $-0.6 / 0$ mode: -0.4 & $-26.7 /-21.5$, mode: -25 & $-47.5 /-34$, mode: -46 & $-0.1 / 0$, mode: 0 \\
\hline$T_{\mathrm{S}}\left({ }^{\circ} \mathrm{C}\right)(110)$ & - & - & $120 / 220$ mode: 150 & - \\
\hline$T_{\mathrm{H}}\left({ }^{\circ} \mathrm{C}\right)(935)$ & $140 / 300$ mode: 250 & $70 / 160$ mode: 120 & $60 / 160$ mode: 130 & $140 / 300$ mode: 260 \\
\hline Salinity & - & $\begin{array}{l}16 / 24 \text { wt } \% \mathrm{NaCl} \\
1 / 12 \mathrm{wt} \% \mathrm{CaCl}_{2}\end{array}$ & $\begin{array}{l}7 / 15 \text { wt } \% \mathrm{NaCl} \\
21 / 27 \text { wt } \% \mathrm{CaCl}_{2}\end{array}$ & - \\
\hline Bulk salinity (equiv. wt $\% \mathrm{NaCl}$ ) & 0/1 mode: 0.6 & $24 / 27.3$ mode: 26 & $30 / 38.1$ mode: 37 & $0 / 0.2$ mode: 0 \\
\hline $\mathrm{NaCl} / \mathrm{NaCl}+\mathrm{CaCl}_{2}$ & - & $0.6 / 0.95$ & $0.2 / 0.35$ & - \\
\hline
\end{tabular}

terminate abruptly within the crystal. Lw1 inclusions occur in all vein types.

$L w 2$ : inclusions are primary and located in the margins of the crystals (QIII) (Fig. 2b). They can also be secondary, scattered along healed fractures in the centre of the crystals (QII) (Fig. 2c). They contain liquid + vapour at room temperature.

$L w-h$ : inclusions contain at least three phases (liquid + vapour + solid) at room temperature including a daughter crystal (Fig. 2d). They occur as pseudosecondary inclusions in QIII and, as trails of secondary inclusions cross-cutting Lw1 and Lw2 fluid inclusion populations. This inclusion type represents the last hydrothermal event in the barren quartz veins. Lw2 and Lw-h fluid inclusions are absent in the gneiss-hosted quartz veins.

\subsection{Microthemometric results}

Results are summarised in Table 2, together with all microthermometric abbreviations used in the text.

\subsubsection{Lw1 inclusions}

The first observable melting of ice takes place at around $-25{ }^{\circ} \mathrm{C}$. These eutectics are consistent with the interpretation of an aqueous solution belonging to the $\mathrm{H}_{2} \mathrm{O}-\mathrm{NaCl}$ system (Shepherd, Rankin, \& Alderton, 1985). The $T_{\text {MICE }}$ values $\left(-0.6\right.$ to $0^{\circ} \mathrm{C}$; mode: -0.4$)$ indicate low salinity, lower than 1 wt\% $\mathrm{NaCl}$. $T_{\mathrm{HL}-\mathrm{V}}$ are in the range of $140-300^{\circ} \mathrm{C}$, with $250^{\circ} \mathrm{C}$ as the modal value (Fig. 3).

\subsubsection{Lw2 inclusions}

Values of $T_{\mathrm{FM}}$, ranging from -67 to $-55^{\circ} \mathrm{C}$ (mode: $-61{ }^{\circ} \mathrm{C}$ ) and the brown-coloured character of crystals are both consistent with the presence of $\mathrm{CaCl}_{2}$ in the fluid
(Shepherd et al., 1985). However the temperatures are lower than the theoretical eutectic temperature in the $\mathrm{H}_{2} \mathrm{O}-\mathrm{NaCl}-\mathrm{CaCl}_{2}$ system, $\sim-52{ }^{\circ} \mathrm{C}$ (Borisenko, 1977; Yanatieva, 1946). Such low $T_{\mathrm{FM}}$ values have been attributed to (i) a melting sequence according to the model univariant curve with a metastable eutectic point of around $-70^{\circ} \mathrm{C}$ (Davis, Lowenstein, \& Spencer, 1990; Spencer, Moller, \& Weare, 1990), and/or (ii) to the presence of additional components such LiCl (Zwart \& Touret, 1994). Microthermometric analyses are based on measuring solidliquid transition temperatures $\left(T_{\mathrm{FM}}, T_{\mathrm{MICE}}\right.$, or $\left.T_{\mathrm{HH}}\right)$. However, first-melting temperatures and identification of freezing-phases are indeed difficult to recognise, and are prone to error and misinterpretation. Raman spectra data from frozen solution in the system $\mathrm{H}_{2} \mathrm{O}-$ $\mathrm{NaCl}-\mathrm{CaCl}_{2}$ indicate that at least some phase transitions between about -70 and $-50^{\circ} \mathrm{C}$ represent a crystallization event (hydrohalite and antarcticite crystallization) and not a metastable melting event (Samson \& Walker, 2000). The demostrated existence of these crystallization events in natural fluid inclusions could lead unwarranted the interpretation of phase transitions below $-50^{\circ} \mathrm{C}$ (Samson \& Walker, 2000).

Hydrohalite melting $T_{\mathrm{HH}}\left(-18.2\right.$ to $-2{ }^{\circ} \mathrm{C}$; mode: $\left.-8{ }^{\circ} \mathrm{C}\right)$ occurs after ice melting $T_{\text {MICE }}\left(-26.7\right.$ to $-21.5^{\circ} \mathrm{C}$; mode: $-25^{\circ} \mathrm{C}$ ). The composition of these fluids has been calculated using an Excel-macro (Naden, 1996), and lies in the high salinity part of the $\mathrm{H}_{2} \mathrm{O}-\mathrm{NaCl}-\mathrm{CaCl}_{2}$ system, below the ice-hydrohalite cotectic curve around 16-24 wt $\% \mathrm{NaCl}$ and $1-12$ wt $\% \mathrm{CaCl}_{2}$. The bulk salinity ranges between 24 and 27.3 equiv. wt\% $\mathrm{NaCl}$ (mode: 26 equiv. wt\% $\mathrm{NaCl}$ ). Lw2 inclusions homogenise to liquid and show lower temperatures (70-160 and $120^{\circ} \mathrm{C}$ as the modal value) than the Lw1 fluids. 


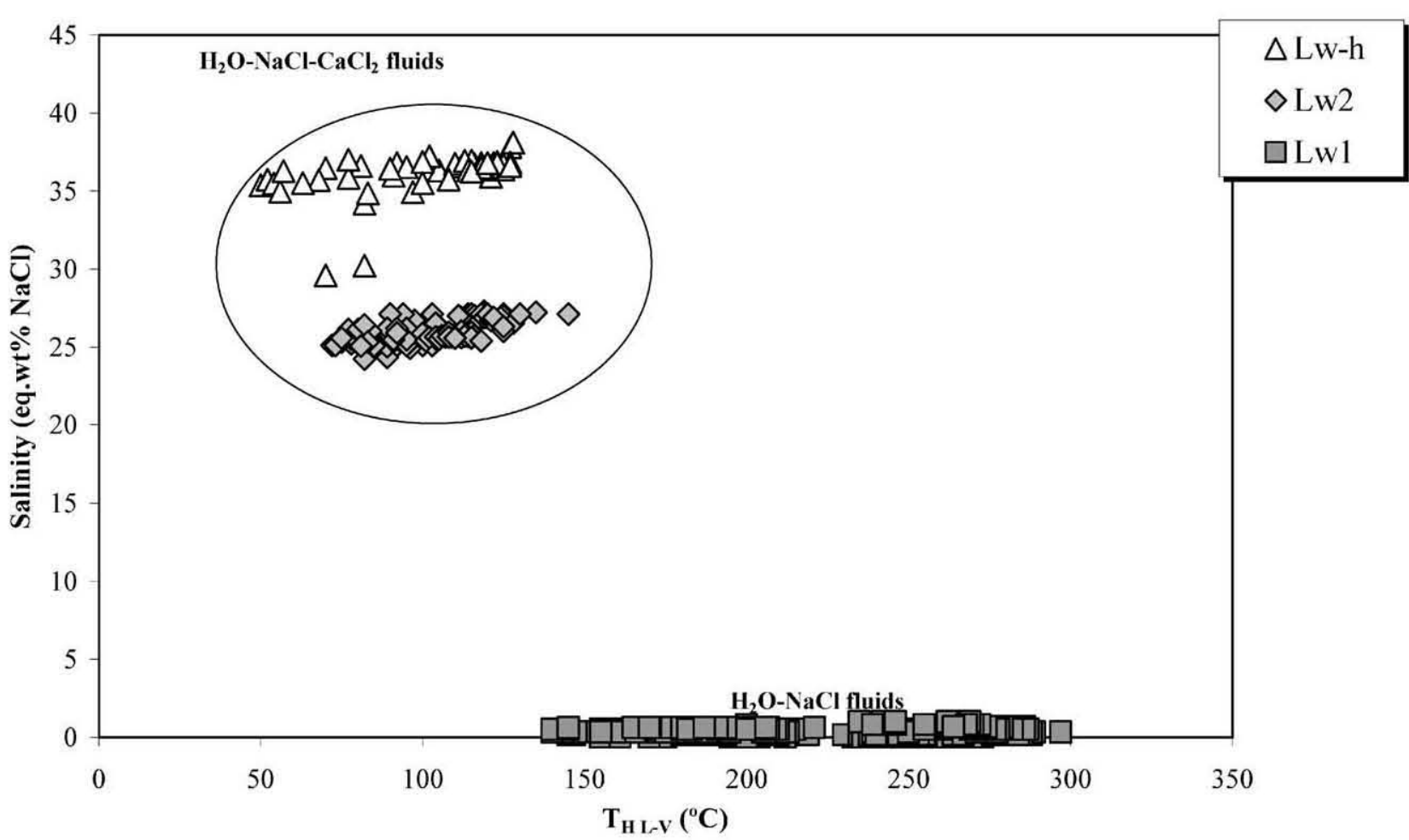

Fig. 3. $T_{\mathrm{H}} \mathrm{L}-\mathrm{V}$ vs salinitity plot for Lw1, Lw2 and Lw-h fluid inclusions. Lw1 type display two populations showing $T_{\mathrm{H} \text { L-V }}$ ranges between $140-220$ and $230-$ $300^{\circ} \mathrm{C}$.

\subsection{3. $L w-h$ inclusions}

These inclusions contain at least three phases at room temperature including a daughter halite crystal. The other solids are interpreted as trapped crystals because they do not dissolve or start to dissolve during heating, and are anomalously large compared to their host inclusions and constant liquid/solid volume ratios are not giving. Some of these have been identified as plagioclase and lamellar muscovite using SEM + EDS combining the morphology of the solids with qualitative chemical analysis. $T_{\mathrm{H} \text { L-V }}$ homogenisation temperatures range from 60 to $160^{\circ} \mathrm{C}$ (mode: $130^{\circ} \mathrm{C}$ ), and dissolution temperatures of halite from 120 to $220^{\circ} \mathrm{C}$ (mode: $150^{\circ} \mathrm{C}$ ). An approximation to the high bulk salinity has been calculated for the $\mathrm{Lw}-\mathrm{h}$ inclusions at between 30 and 38.1 equiv. wt\% $\mathrm{NaCl}$ (mode: 37 equiv. wt\% $\mathrm{NaCl}$ ). The estimated compositions (calculated by a Microsoft Excel add-in, Naden, 1996) are $7-15 \mathrm{wt} \% \mathrm{NaCl}$ and 21-27 wt\% $\mathrm{CaCl}_{2}$. Lw-h inclusions show dissolution temperatures of halite that are higher than homogenisation temperatures $\left(T_{\mathrm{S}}>T_{\mathrm{H}}\right)$. It is likely that $\mathrm{Lw}-\mathrm{h}$ inclusions have a possible mixture of additional components such as $\mathrm{KCl}, \mathrm{LiCl}$ or $\mathrm{H}_{2} \mathrm{~S}$ (Zwart \& Touret, 1994).

A $T_{\mathrm{H}}$-salinity plot (Fig. 4a) indicates the presence of two fluids of different salinity but with a similar $T_{\mathrm{H}}$ range $\left(70-140^{\circ} \mathrm{C}\right)$. Lw2 inclusions are less saline than pseudosecondary and secondary Lw-h inclusions, thus indicating a progression to higher salinity with quartz crystallization.

The $\mathrm{Lw}-\mathrm{h}$ fluid is enriched in Ca relative to the $\mathrm{Lw} 2$ type
(Fig. 4b). Slight differences in the $\mathrm{NaCl} / \mathrm{NaCl}+\mathrm{CaCl}_{2}$ ratio can be observed between the different quartz veins. The $\mathrm{La}$ Cabrera vein, which is located in the northern part of the area, contains $\mathrm{Lw} 2$ inclusions with high $\mathrm{NaCl} / \mathrm{NaCl}+\mathrm{CaCl}_{2}$ ratios; no $\mathrm{Lw}$-h inclusions were observed. $\mathrm{Lw} 2$ fluid inclusions from Colmenarejo quartz veins, which are located in the southern part of the region, are more calcic. Inclusions from the other veins, Manzanares and Cerceda, show a wide range in $\mathrm{Na} / \mathrm{Ca}$ rations and typically have lower $T_{\mathrm{H}}$ values.

\subsection{Ion analyses}

The atomic ratios $\mathrm{Na} / \mathrm{Ca}$ and $\mathrm{Na} / \mathrm{Li}$ were measured in $\mathrm{Lw} 2$ and $\mathrm{Lw}-\mathrm{h}$ inclusions, however ratios in Lw1 inclusions could not be estimated due to their low salinity. Mole ratios for $\mathrm{Lw} 2$ inclusions are: $\mathrm{Na} / \mathrm{Ca}=7$ and $\mathrm{Na} / \mathrm{Li}=14$. $\mathrm{Lw}-\mathrm{h}$ inclusions show an enrichment in $\mathrm{Ca}$ and $\mathrm{Li}(\mathrm{Na} / \mathrm{Ca}=1.5$, $\mathrm{Na} / \mathrm{Li}=3$ ) with respect to $\mathrm{Lw} 2$ inclusion. These ratios confirm the presence of significant amounts of $\mathrm{Li}$ in $\mathrm{Lw} 2$ and $\mathrm{Lw}-\mathrm{h}$ inclusions. Moreover, an enrichment in $\mathrm{Li}$ and $\mathrm{Ca}$ content is observed from the $\mathrm{Lw} 2$ to the $\mathrm{Lw}-\mathrm{h}$ inclusions. $\mathrm{Li}$ concentrations have been measured in quartz crystals and range from 0 to $400 \mathrm{ppm}$.

Previously published data on bulk crush-leach analyses (Martín Crespo et al., 1999) are considered in this study. Samples chosen from the barren quartz veins for bulk chemical analysis offluid inclusion leachates are characterised by a single inclusion type, representative of the higher salinity $\mathrm{Lw} 2$ fluids. The $\mathrm{C} / \mathrm{Br}$ molar ratio (703 to 753 ) and 

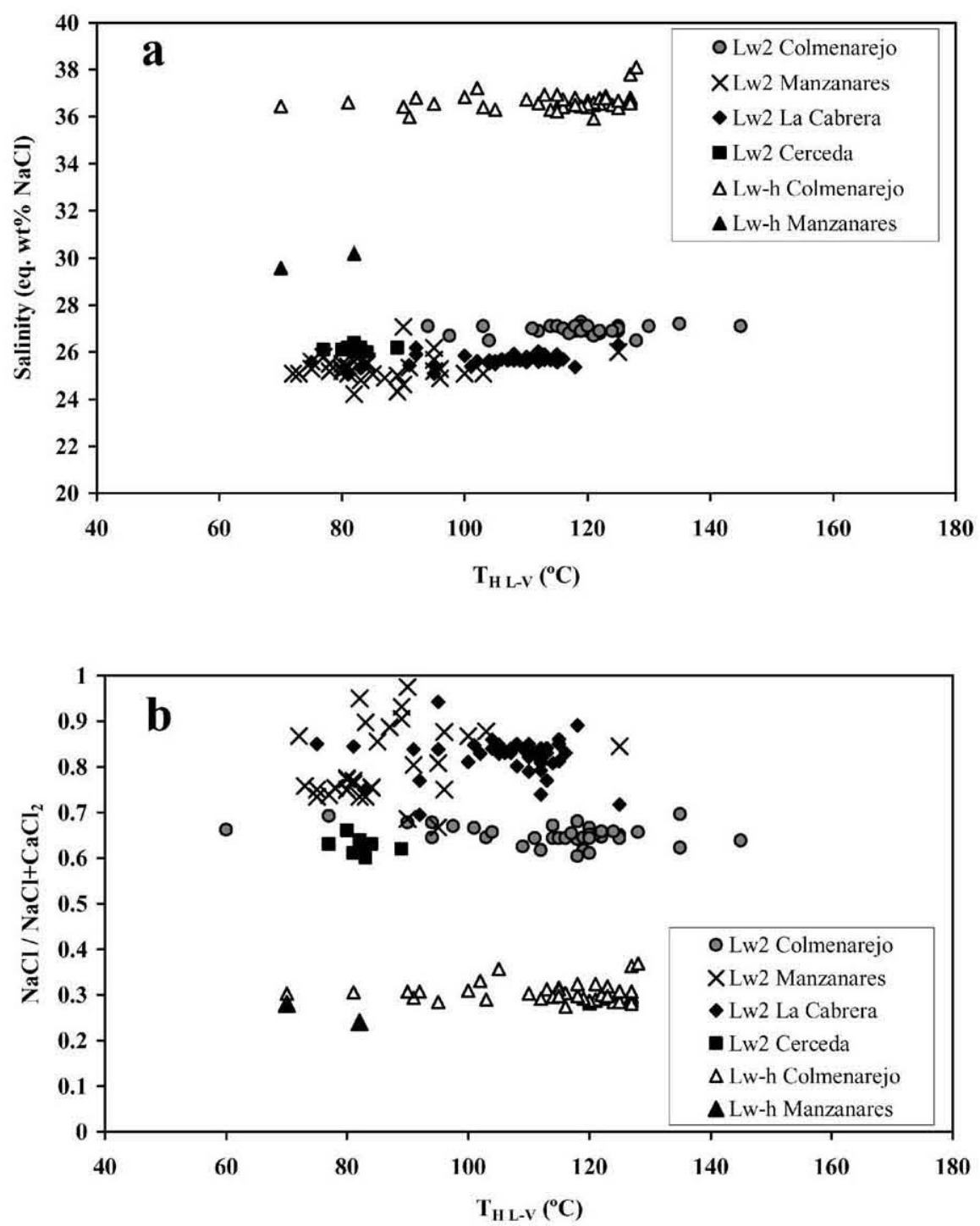

Fig. 4. $\mathrm{Lw} 2$ and $\mathrm{Lw}-\mathrm{h}$ inclusions $\left(\mathrm{H}_{2} \mathrm{O}-\mathrm{NaCl}-\mathrm{CaCl}_{2}\right)$. (a) $T_{\mathrm{H} \mathrm{L}-\mathrm{v}}$ vs salinity plot. (b) $T_{\mathrm{H} L-\mathrm{v}}$ vs $\mathrm{NaCl} / \mathrm{NaCl}+\mathrm{CaCl}$.

$\mathrm{Na} / \mathrm{Br}$ molar ratio (508 to 1054 ) is close to the ratio for seawater (Cl/Br: 655 and Na/Br: 562, after Horita, Friedman, Lazar, \& Holland, 1991), but slightly impoverished in Br.

\section{6. $P-T$ conditions}

A reconstruction of the $P-T$ conditions that prevailed during the entrapment of the fluids is given in Fig. 5.

The latest stage of quartz deposition is characterised by the circulation of $\mathrm{H}_{2} \mathrm{O}-\mathrm{NaCl}-\mathrm{CaCl}_{2}$ fluids. Since $\mathrm{Lw} 2$ and $\mathrm{Lw}$-h inclusions show no evidence of boiling, and a mineral geothermometer is not available, fluid pressure is assumed to be greater than or equal to hydrosthatic pressure $\left(P_{\mathrm{h}}\right)$. Vuggy textures and the brittle nature of the host rock are taken as indicators of a hydrostatic pressure regime for this fluid. Maximum fluid pressures were constrained by the maximum depth of burial. Late Hercynian granites in the Spanish Central System were emplaced at depths of between 5 and $8 \mathrm{~km}$, under a lithostatic pressure at $\sim 2 \mathrm{kbar}$ (Villaseca et al., 1998). If the pressure regime was entirely hydrostatic, a depth of $5 \mathrm{~km}$ indicates a $P_{\text {fluid }}$ of less than $0.5 \mathrm{kbar}$. For this pressure range, the $\mathrm{CaCl}_{2}$ bearing fluids were trapped at $70-140^{\circ} \mathrm{C}$ (Fig. 5).

The early stage of hydrothermal circulation is characterised by a $\mathrm{H}_{2} \mathrm{O}-\mathrm{NaCl}$ fluid represented by low salinity inclusions. The mineral assemblage provides no additional constraints on the $P-T$ conditions. Although $T_{\mathrm{H}}$ ranges between $140-220$ and $230-300{ }^{\circ} \mathrm{C}$, the most probable conditions for this stage are derived for modal isochores having $T_{\mathrm{H}}$ in the $230-300{ }^{\circ} \mathrm{C}$ range. The $T_{\mathrm{H}}$ range between 140 and $220^{\circ} \mathrm{C}$ has been only measured in some fluid inclusions from the single quartz vein of the La Cabrera, and has not been considered representative data for $P-T$ estimations. Trapping pressures are difficult to estimate precisely, but a maximum depth of $5 \mathrm{~km}$ suggests pressures $<1 \mathrm{kbar}$, assuming a transition from lithostatic to hydrostatic pressure 


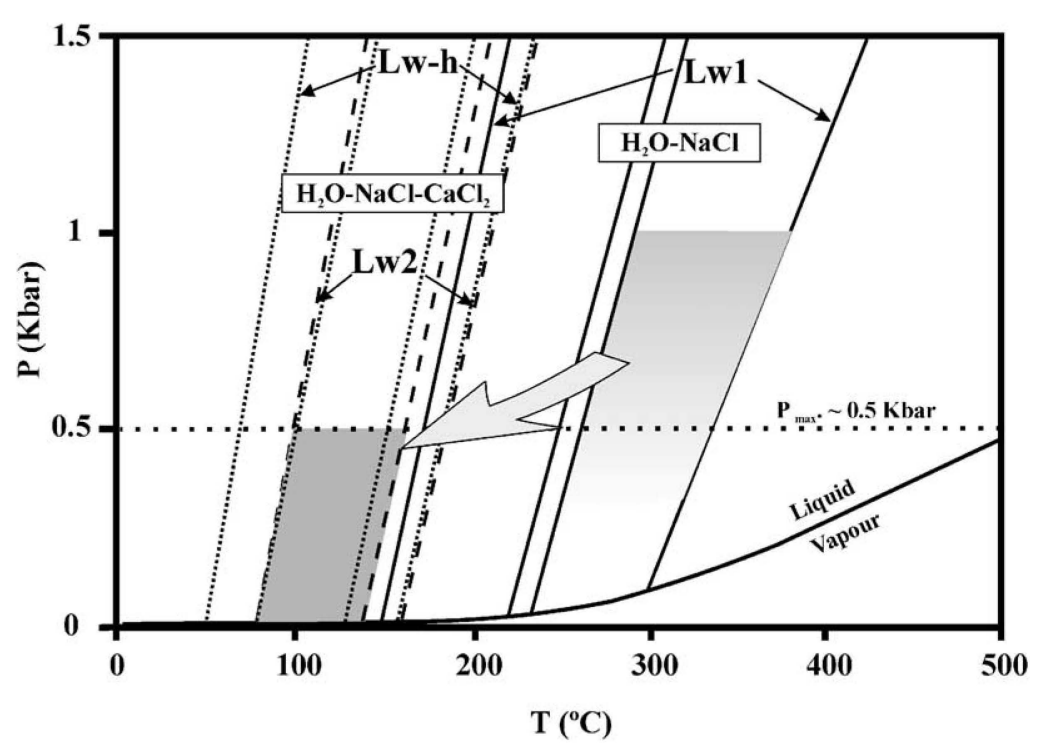

Fig. 5. Pressure-temperature diagram showing $P-T$ constraints for different inclusion types. The isochores for the fluids have been drawn for each inclusion type: Lw1: solid lines; Lw2: dashed lines; Lw-h: dotted lines. The field for Lw1 inclusions (light grey) is determined by the isochores (modal range) and a assumed maximun $P_{\text {fluid }} \sim 1$ kbar. The field for Lw2 inclusions (dark grey) is determined by intersection of isochores (modal range), and calculated maximum $P_{\text {fluid }}$ under hydrostatic regime.

regime during the earlier hydrothermal circulation stages. The overall fluid evolution shows a decreasing trend in the temperature and a progressive enrichment in $\mathrm{NaCl}$ and $\mathrm{CaCl}_{2}$ content.

\section{7. ${ }^{39} \mathrm{Ar} /{ }^{40} \mathrm{Ar}$ geochronology}

To constrain the evolution of the fluids, hydrothermal muscovites from granite-hosted quartz veins (Colmenarejo) were analysed by the ${ }^{39} \mathrm{Ar} /{ }^{40} \mathrm{Ar}$ method. The spectrum obtained has a staircase shape (Fig. 6). A 'plateau' age of $274 \pm 5 \mathrm{Ma}$ is suggested by three of the four late steps between 45 and $95 \%$ fractional ${ }^{39} \mathrm{Ar}$ release. The steps with the lowest age could be explained by diffusion processes and by some post-crystallization heating, mainly at the border of the samples because of the later hydrothermal heating events. Several Mesozoic hydrothermal events have been recognised in the Spanish Central System, and Villa (1998) has shown that fluid-mineral interaction is more relevant for isotopic exchange compared to the thermal history of a mineral. Anyhow, the later hydrothermal

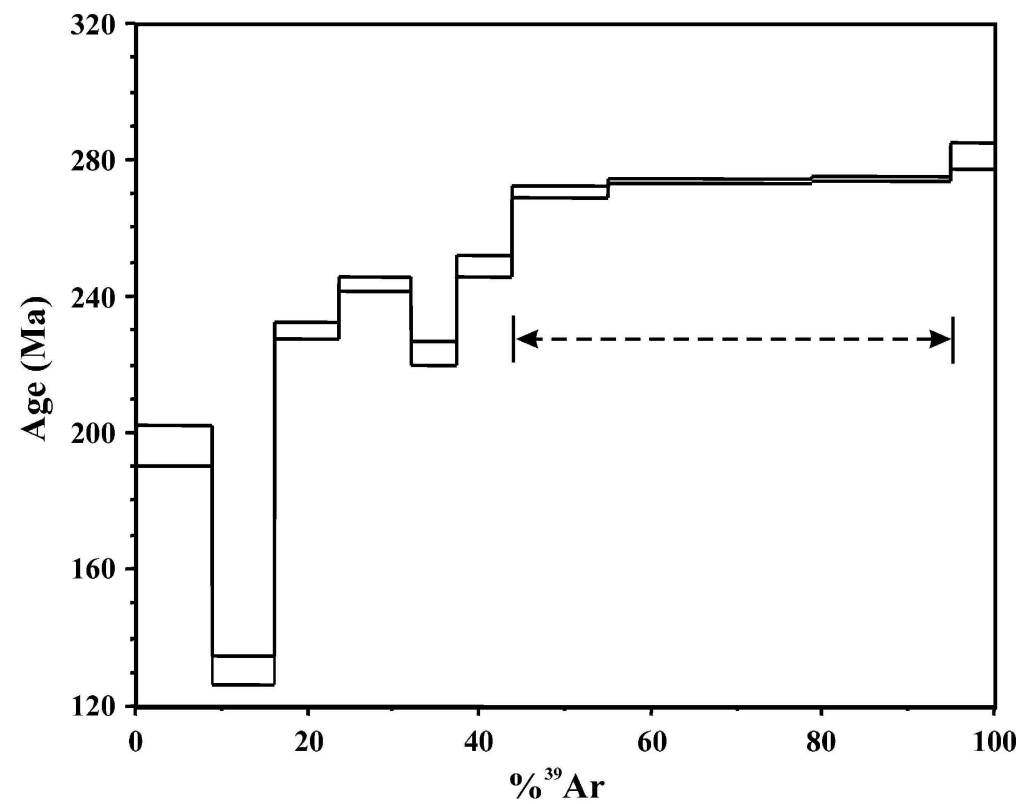

Fig. 6. Age spectrum of hydrothermal white mica. The spectrum obtained has a staircase shape and the 'plateau' is suggested by three of the four late steps. 
Stable isotope data. Measured (Meas.) fluid $\delta \mathrm{D}$ and $\delta^{18} \mathrm{O}$ are bulk values for the total fluid inclusion population and quartz, respectively. Calculated (Calc.) fluid $\delta^{18} \mathrm{O}$ values are derived from the bulk mineral data by means of fractionation factors at the appropriate temperature (Clayton et al., 1972) (N.D.: not determined)

\begin{tabular}{|c|c|c|c|c|c|c|c|}
\hline Sample & Fluid type & $\begin{array}{l}\text { Inclusion } \\
\text { type }\end{array}$ & $\begin{array}{l}\text { Minimum } \\
\text { fluid trapping } \\
\text { temperature }\left({ }^{\circ} \mathrm{C}\right)^{\mathrm{a}}\end{array}$ & $\begin{array}{l}\text { Modal salinity of } \\
\text { fluid inclusions } \\
\text { (wt } \% \mathrm{NaCl} \text { equiv.) }\end{array}$ & $\begin{array}{l}\text { Meas. quartz } \\
\delta^{18} \mathrm{O}_{\text {SMOW }}(\% \circ)\end{array}$ & $\begin{array}{l}\text { Calc. } \\
\text { quartz-fluid } \\
\delta^{18} \mathrm{O}_{\text {SMOW }}(\%)^{\mathrm{b}}\end{array}$ & $\begin{array}{l}\text { Meas. bulk } \\
\text { fluid } \mathrm{H}_{2} \mathrm{O} \\
\delta \mathrm{D}_{\text {SMOW }}(\% o)\end{array}$ \\
\hline Cer. G3 & \multirow{3}{*}{$\mathrm{H}_{2} \mathrm{O}-\mathrm{NaCl}$} & Lw1 & $140-290$ & 1 & 8.1 & $-8 / 1$ & -55 \\
\hline Man.G1 & & Lw1 & $230-300$ & 0.3 & 6.9 & $-7.3 / 1.5$ & $-38 /-59$ \\
\hline Cab.G2 & & Lw1 & $140-230$ & 0.5 & 10.6 & $-5.3 / 1.5$ & $-71 /-73.5$ \\
\hline Col. G4 & \multirow[t]{4}{*}{$\mathrm{H}_{2} \mathrm{O}-\mathrm{NaCl}-\mathrm{CaCl}_{2}$} & Lw2 & $90-160$ & 27 & 6.7 & $-20 /-7.8$ & -116 \\
\hline Cer. G2 & & Lw2 & $75-90$ & 26.2 & N.D. & N.D. & N.D. \\
\hline Man.G4 & & Lw2 & $70-115$ & 25.5 & 8.5 & $-17 /-6$ & -137 \\
\hline Cab.G1 & & Lw2 & $75-130$ & 25.7 & N.D. & N.D. & N.D. \\
\hline
\end{tabular}

\footnotetext{
${ }^{a}$ Fluid inclusions temperature range.

b Calculated using equations of Clayton et al. (1972) at the appropiate temperature.

c Anomalous data because of probably mixing with Lw2 inclusions.
}

temperatures have not raised the closure temperature for muscovites (Villa, 1998).

The age determined in the present study is higher than previously reported for sericite from phyllic alteration surrounding barren quartz veins, which was dated by the $\mathrm{K}-\mathrm{Ar}$ method at $100 \pm 4 \mathrm{Ma}$ (Caballero et al., 1992). The large difference between the two ages suggests that two different hydrothermal events have been dated. The muscovite age determined in this work may correspond to the first hydrothermal stage. Alteration events around $270 \mathrm{Ma}$ coincide with Permian extensional tectonics, and with a major hydrothermal phase in the Spanish Central System. The hydrothermal stage dated around $100 \mathrm{Ma}$ corresponds to Lower Cretaceous, could be related to the later Ca-bearing fluids present in the barren quartz veins and considered as a younger reactivation of the faults.

\section{Stable isotope results}

The isotopic composition of the fluid have been measured (Meas.) for the $\delta \mathrm{D}$ values and calculated (Calc.) for the $\delta^{18} \mathrm{O}$ values (Table 3 ).

The Lw1 fluid in granite-hosted veins shows a range of bulk $\delta \mathrm{D}\left(-70\right.$ to $-38 \%$ ) and $\delta^{18} \mathrm{O}(-8$ to $1 \%$ ), comparable to values in gneiss-hosted veins $(-64$ to $-34.5 \%$ for $\delta \mathrm{D}$ and -9 to $2 \%$ for $\delta^{18} \mathrm{O}$ ). The low $\delta^{18} \mathrm{O}$ values indicate a meteoric origin for the water, although the more positive values can be related to the interactions water-rocks (Fig. 7). An origin from seawater can be excluded since evaporated seawater will be close to halite saturation ( $\sim 26.3$ equiv. wt $\% \mathrm{NaCl}$; Holser, 1979), and the Lw1 fluid contains only 0.151 equiv. wt $\% \mathrm{NaCl}$.

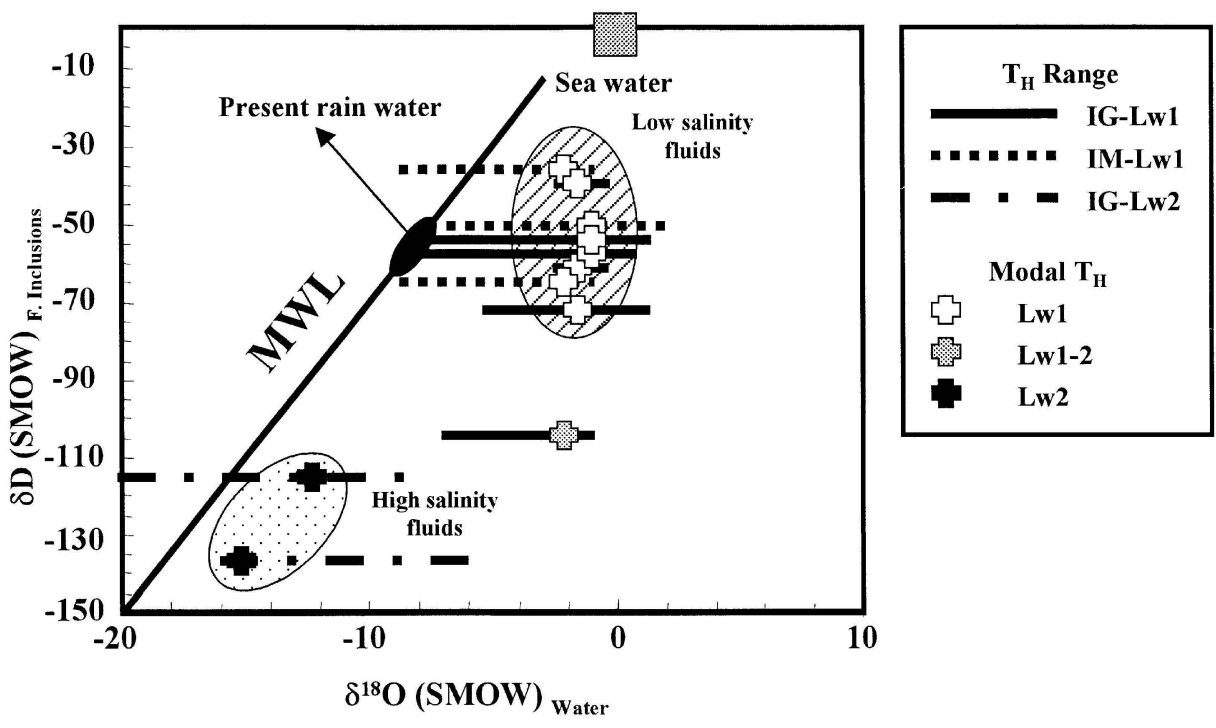

Fig. 7. $\delta^{18} \mathrm{O}-\delta \mathrm{D}$ plot of Lw1 and Lw2 inclusions (GRH: granite-hosted veins, GNH: gneiss-hosted veins). Range in $\delta^{18} \mathrm{O}$ corresponds to maximum and minimum trapped temperatures (Table 3 ). 
The Lw2 fluid inclusions are only present in a granitehosted quartz vein. The Lw 2 fluid inclusion $\delta \mathrm{D}$ values cluster between -137 and $-116 \%$ and $\delta^{18} \mathrm{O}$ values between -20 and $-6 \%$. The low $\delta^{18} \mathrm{O}$ and $\delta \mathrm{D}$ range estimated for Lw2 fluid indicate a meteoric origin for the fluid. However, its high salinity $(25.7-27$ equiv. wt $\% \mathrm{NaCl}$ ) could indicate dissolution of evaporites. $\delta \mathrm{D}$ values are lower than those reported for other hydrothermal events involving meteoric fluids in the Spanish Central System (Tornos, Delgado, Casquet, \& Galindo, 2000). Several possible origins for anomalously low $\delta \mathrm{D}$ values such as those reported here have been argued (Gleeson, Wilkinson, Boyce, Fallick, \& Stuart, 1999): (i) water-organic matter interactions; (ii) contributions of hydrogen with different isotopic signature from mica trapped in fluid inclusions; (iii) post-entrapment hydrogen diffusion; and (iv) high-latitude and high-altitude meteoric precipitation. The first possibility can be ruled out because of the lack of organic matter. A source of hydrogen from micas and hydrogen diffusion could be considered. Trapped micas have been recognised in Lw1 and Lw2 fluid inclusions, however anomalously $\delta \mathrm{D}$ values in Lw1 fluid inclusions have not been recognised. Therefore, the contribution of hydrogen from trapped mica could be considered as negligible. Post-entrapment hydrogen diffusion from hosted quartz to fluid inclusion could be taken into account. Low $\delta \mathrm{D}$ values have been reported from quartz interstitial sites relative to molecular water, although the hydrogen isotope fractionation factors for the incorporation of hydrogen into quartz interstitial sites are unknown (Gleeson, Grant, \& Roberts, 2000).

Anomalously low $\delta \mathrm{D}$ are often interpreted to indicate the involvement of high latitude/altitude meteoric waters in palaeoflow systems, which seems to be the main reason to explain such low $\delta \mathrm{D}$ values in Lw2 fluids.

Few data lie away from the isotopically well defined Lw1 group. These intermediate values between $L w 1$ and $L w 2 \delta D$ data can be attributed to a mixture of $L w 1$ and $L w 2$ fluid inclusions. In the analysed sample the inclusions were not exclusively Lw1 and some Lw2 inclusions were also included.

\section{Discussion}

The early ( $\mathrm{Lw1}$ ) $\mathrm{H}_{2} \mathrm{O}-\mathrm{NaCl}$ fluid inclusions represent a high $\delta \mathrm{D}, \delta^{18} \mathrm{O}$, high temperature and low salinity fluid consistent with an origin related to meteoric waters.

Fluids characterised as $\mathrm{H}_{2} \mathrm{O}-\mathrm{NaCl}$ have been recognised as being associated with earlier hydrothermal events of several age at the Sierra de Guadarrama: W-(Sn)-sulphide veins (García et al., 1999a; Vindel et al., 1995), epysienites (Caballero, 1993), As-(Ag) mineralizations (García et al., 1999b) and barite-fluorite ( $\mathrm{Pb}-\mathrm{Zn}$ ) veins (Tornos et al., 1991). Therefore this type of fluid was present during all hydrothemal activity in the area.

The $\mathrm{H}_{2} \mathrm{O}-\mathrm{NaCl}-\mathrm{CaCl}_{2}$ fluids represent a late and minor event relative to the $\mathrm{H}_{2} \mathrm{O}-\mathrm{NaCl}$ fluids, and are restricted to granite-hosted veins. The absence of $\mathrm{Ca}$-fluid inclusions in the gneiss-hosted quartz veins could be related to the hosted lithology. Foliation of gneisses could favour the fluid migration out of the veins. Stable isotope data indicate a meteoric origin for the $\mathrm{H}_{2} \mathrm{O}-\mathrm{NaCl}-\mathrm{CaCl}_{2}$ fluid, but the high salinity was probably derived from dissolution of evaporites. The age of the late fluid is $\leq 100 \mathrm{Ma}$, allowing the possibility that the fluid percolated through Triassic evaporites. Significant Mesozoic evaporitic basins are located in the northeast of the Spanish Central System (SCS) (Utrilla, Ortí, Pueyo, \& Pierre, 1989; Utrilla, Pierre, Ortí, \& Pueyo, 1992). The northern (Atlantic domain) and southern (Tethys domain) parts of the SCS were connected during the Cretaceous via NE-SW and NW-SE faults (Casas et al., 1998). Both sedimentary basins were palaeogeographically linked (Gil \& García, 1996).

Li represent a good tracer of the evaporitic evolution of primary solutions. It behaves conservatively during seawater concentration and evaporite precipitation (Fontes \& Matray, 1993). Significant Li concentrations in quartz crystals and in the $\mathrm{H}_{2} \mathrm{O}-\mathrm{NaCl}-\mathrm{CaCl}_{2}$ fluid were measured. High $\mathrm{Li}$ concentration have been typically reported from evaporitic sequences and attributed to highly concentrated brines (Fontes \& Matray, 1993). $\mathrm{Na} / \mathrm{Br}$ and $\mathrm{Cl} / \mathrm{Br}$ ratios can be used to distinguish ions from different sources (Kesler et al., 1995). Halogens ( $\mathrm{Cl} / \mathrm{Br}$ and $\mathrm{Na} / \mathrm{Br}$ ratios) from crushleach analysis could represent their original seawater signature in a marine/evaporitic environment.

Moreover, the $\mathrm{CaCl}_{2}$ content is also consistent with dissolution of evaporites, thus other Ca sources are not necessary. Sedimentary carbonates (higher $\delta^{18} \mathrm{O}$ ) and lower waterrock ratios are concordant with diagenetic water enriched in ${ }^{18} \mathrm{O}$ but not in D (Fig. 7).

It is important to stress that during Cretaceous time, this area was a low latitude (Ziegler, Scotese, \& Barret, 1983). At present, the oxygen isotopic composition of meteoric water in latitudes between 0 and $20^{\circ}$ is typified by values ranging between +1.5 and $-7 \%$ (SMOW) (Rozanski, Araguás, \& Gonfiantini, 1993). Ocean waters during the Mesozoic Era were between 2.3 and 1.2\%o lighter than at present (Scherer, 1977; Shackleton \& Kennett, 1975). Therefore, a meteoric water derived from the evaporation of marine waters at that time could fall between -0.8 and $-9.3 \%$ (SMOW). Even so, the measured $(-137 \% \circ<\delta \mathrm{D}<-116 \%)$ and calculated $\left(-20 \%<<\delta^{18} \mathrm{O}<-6 \%\right.$ ) isotopic composition of the fluids are too negative to be explained by differences in seawater composition. Most explanations for $\mathrm{H}_{2} \mathrm{O}-\mathrm{NaCl}-\mathrm{CaCl}_{2}$ fluids with anomalously low $\delta \mathrm{D}$ values are related to high-latitude and/or high altitude meteoric precipitation (Gleeson et al., 1999). However, palaeogeographic reconstructions of the Lower Cretaceous in this part of the Spanish Central System (Alonso, Floquet, Meléndez, \& Salomón, 1982) indicate intermediate latitude close to the Cancer Tropic. Therefore, none of the previously 
documented hypotheses for the formation of anomalously low $\delta \mathrm{D}$ fluids can adequately explain the occurrence of this type of fluids in the Spanish Central System during the Lower Cretaceous. However, other authors such as Dutta and Suttner (1986) and Marfil, Delgado, Rossi, La Iglesia, and Ramseyer (2000), studying kaolinites from this period, have also reported anomalously low isotopic values (compared to recent kaolinites that were formed in weathering profiles at low latitudes). A possible explanation could be the so called 'amount effect', that leads to more negative rain waters than expected at these latitudes (Fontes, 1980; Rozanski et al., 1993). At middle and lower latitudes, the isotopic content of precipitation is found to be higher in small amounts of rain but never near the poles. Highly depleted oxygen isotope values of actual and recent sediments indicate an origin related with wet periods characterised by intense tropical summer (monsoonal) rainfall with heavy thunderstorms (Luckge, Doose-Rolinski, Khan, Schulz, \& Von Rad, 2001). Therefore, we should expect strong isotopic depletion in meteoric waters, such as those observed in modern areas with monsoonal climates (Feng, Cui, Tang, \& Conkey, 1999; Marfil et al., 2000). Thus, periods of high precipitation and dissolution of evaporites may have promoted the formation of Lw2 fluids in equilibrium with very negative and high salinity waters. This data are concordant with the general climate of the Late Jurassic and Lower Cretaceous characterised by high atmospheric $\mathrm{CO}_{2}$ levels and by a monsoonal rainfall pattern (Weissert \& Mohr, 1996).

$\mathrm{CaCl}_{2}$-rich brines with moderate to high salinity often occur around the margins of Mesozoic basins of central Europe, particularly in the vicinity of older granites (Heijlen, Muchez, Banks, \& Nielsen, 2000; Lodemann et al., 1998; Muchez et al., 1995; Munoz et al., 1994; O'Reilly et al., 1997; Wilkinson et al., 1995), and have been related to the early north Atlantic rifting and associated to the Triassic-Jurassic evaporites (Halliday \& Mitchell, 1984; Mitchell \& Halliday, 1976; Munoz et al., 1999; O'Connor et al., 1993). Mineralizations can be spatially correlated to the granites formed by post-orogenic collapse in relation to intense fracturing. It is proposed that high salinity $\mathrm{H}_{2} \mathrm{O}-$ $\mathrm{NaCl}-\mathrm{CaCl}_{2}$ solutions, that originated from residual evaporite brines and formation waters, infiltrated into the basement along extensional structures (Behr \& Gerler, 1987; Behr, Reutel, Horn, \& Van den Kerkhof, 1994, Reutel, Behr, Horn, Van den Kerkhof, 1994). Other models propose a fluid flow system involving meteoric water that increased in salinity because of interaction with evaporiticbearing sequences, related to the Mesozoic extensional events (Muchez \& Sintubin, 1998; Munoz et al., 1999). Fluid migration during Mesozoic time in the Spanish Central System belongs to a general history in the Variscan range, and can be compared to the model described in Munoz et al. (1999) for fluids related to major Mesozoic extensional events, coinciding with the opening of the Atlantic and Tethys oceans.

\section{Conclusions}

Barren quartz veins represent the latest event of the hydrothermal evolution in the Sierra de Guadarrama (Spanish Central System) and are characterised by two different fluids. The first fluid is represented by the $\mathrm{H}_{2} \mathrm{O}-\mathrm{NaCl}$ system and characterised by low salinity. The isotopic data indicate a meteoric origin for this fluid. This early fluid is related to older hydrothermal events in the area: W-Sn-sulphide veins, episienites, As-Ag mineralizations and barite-fluorite veins. The youngest fluid belongs to the $\mathrm{H}_{2} \mathrm{O}-\mathrm{NaCl}-\mathrm{CaCl}_{2}$ system and has high salinity. Ca-brines have not been found in the older hydrothermal events in the Sierra de Guadarrama. This later fluid represents meteoric water salt-enriched by dissolution of Triassic evaporites. Palaeogeographic reconstructions of the Lower Cretaceous in this part of the Spanish Central System do not suggest low $\delta \mathrm{D}$ fluids commonly related to high-latitude and/or highaltitude. The most plausible explanation could be the 'amount effect', that leads to more negative rain waters than expected at tropical latitudes, such as those observed in monsoonal climates.

Fluid composition and evolution in barren quartz veins of the Spanish Central System are similar to other hydrothermal Post-Variscan events in central and south-western Europe. In all cases mineralization occurs around the margins of Mesozoic basins in the vicinity of granites and has been attributed to early Cretaceous Atlantic rifting. However, geochronological data suggest that several hydrothermal phases could be recorded in barren quartz veins up to Cretaceous. The first one $(\sim 270 \mathrm{Ma})$ is ubiquitous throughout the Spanish Central System, and represents a major hydrothermal circulation event, coincident with the Mid-Permian transition to extensional pre-rift tectonics. Other hydrothermal phases continued during the Mesozoic time until the Cretaceous. The late hydrothermal stage $(\sim 100 \mathrm{Ma})$ could be related to Ca-bearing fluids.

\section{Acknowledgements}

M. Christine Boiron (CREGU-G2R, Nancy, France) and I. Villa (Bern University, Switzerland) are thanked for comments and technical support with LIBS and geochronology analysis, respectively. R. Oyarzun is thanked for his careful reading and improvement of the English. TMC acknowledges post-graduate fellowship from the Comunidad de Madrid. The authors thank I. Samson and I.C. Scotchman for their helpful reviews.

\section{References}

Alonso, A., \& Mas, J. R. (1982). Correlación y evolución paleogeográfica del Cretácico al norte y al sur del Sistema Central. Cuadernos de Geología lérica, 8, 145-166. 
Alonso, A., Floquet, M., Meléndez, A., \& Salomón, J. (1982). CamerosCastilla, El Cretácico de España. Madrid: Univ. Complutense pp. 345456.

Behr, H. J., \& Gerler, J. (1987). Inclusions of sedimentary brines in PostVariscan mineralizations in the Federal Republic of Germany-A study by neutron activation analysis. Chemical Geology, 61, 65-77.

Behr, H. J., Horn, E. E., Frentzel-Beyme, K., \& Reutel, Ch. r. (1987). Fluid inclusion characteristic of the Variscan and Post-Variscan mineralizing fluids in the Federal Republic of Germany. Chemical Geology, 61, 273285.

Behr, H. J., Reutel, Ch. r., Horn, E. E., \& Van den Kerkhof, A. M. (1994). The fluid research program of the Continental Deep Drilling Project $\mathrm{KTB}$ (Germany). II. Ca-Na-Cl basement brines as tracers of fluid activity and mineralization in an orogenic collapse system. PACROFI V, Cuemavaca, 8.

Bellido, F., Capote, R., Casquet, C., Fúster, J. M., Navidad, M., Peinado, M., \& Villaseca, C. (1981). Caracteres generales del cinturón hercínico en el sector oriental del Sistema Central Español. Cuadernos de Geología Ibérica, 7, 15-51.

Bodnar, R. J. (1993). Revised equation and table for determining the freezing point depression of $\mathrm{H}_{2} \mathrm{O}-\mathrm{NaCl}$ solutions. Geochimica et Cosmochimica Acta, 57, 683-684.

Boiron, M. C., Dubessy, J., André, N., Briand, A., Lacour, J. L., Mauchien, P., \& Mermet, J. M. (1991). Analysis of mono-atomic ions in individual fluid inclusions by laser-produced plasma emission spectroscopy. Geochimica et Cosmochimica Acta, 55, 917-923.

Boiron, M. C., Essarraj, S., Sellier, E., Cathelineau, M., Lespinasse, M., \& Poty, B. (1992). Identification of fluid inclusions in relation to their host microstructural domains in quartz by cathodoluminescence. Geochimica et Cosmochimica Acta, 56, 175-185.

Boiron, M. C., Moissette, A., Fabre, C., Dubessy, J., Banks, D., \& Yardley, B. W. (1997). Ion analysis in individual fluid inclusions by Laser Ablation-Optical Emission Spectroscopy. Application to natural fluid inclusions. Proceedings of the XIV ECROFI Conference, Nancy, 44.

Borisenko, A. S. (1977). Study of the salt composition of solutions in gasliquid inclusions in minerals by the cryometric method. Soviet Geology and Geophysics, 18, 11-19.

Borthwick, J., \& Harmon, R. (1982). A note regarding $\mathrm{ClF}_{3}$ as an alternative to $\mathrm{BrF}_{5}$ for oxygen from oxygen isotope analysis. Geochimica et Cosmochimica Acta, 46, 1665-1668.

Bottrell, S. H., Yardley, B. W. D., \& Buckley, F. B. (1988). A modified crush-leach method for the analysis of fluid inclusion electrolytes. Bulletin of Mineralogy, 111, 279-290.

Caballero, J. M., Casquet, C., Galindo, C., Gonzalez-Casado, J. M., Snelling, N., \& Tornos, F. (1992). Dating of hidrothermal events in the Sierra de Guadarrama, Teerian Hercynian Belt, Spain. Geogaceta, 11, $18-22$.

Caballero, J. M., (1993). Las episienitas de la Sierra de Guadarrama: un caso singular de alteración hidrotermal de edad post-hercínica. $P h D$ Thesis. Complutense University, Madrid.

Canals, A., \& Cardellach, E. (1993). Strontium and sulphur isotope geochemistry of low-temperature barite-fluorite veins of the Catalonian Coastal Range (NE Spain): A fluid mixing model and age constraints. Chemical Geology, 104, 269-280.

Casas, A., Cortés, A. L., Liesa, C., Soria, A. R., Terrinha, P., Kullberg, J. C., $\&$ da Rocha, R. (1998). Estudio comparado de la evolución e inversión de distintas cuencas mesozoicas de la Placa Tbérica. Geogaceta, 24, 67-70.

Casillas, R., Vialette, Y., Peinado, M., Duthou, J. L., \& Pin, C. (1991). Ages et caracteristiques isotopiques ( $\mathrm{Sr}-\mathrm{Nd}$ ) des granitoides de la Sierra de Guadarrama occidentale (Espagne). In R. Black, B. Bonin, A. Giret \& $\mathrm{P}$. Sabate, Granites oceaniques et continentaux.

Charef, A., \& Sheppard, S. M. F. (1988). The Malines Cambrian carbonate shale-hosted $\mathrm{Pb}-\mathrm{Zn}$ deposit, France: Thermometric and isotopic $(\mathrm{H}, \mathrm{O})$ evidence for pulsating hydrothermal mineralization. Mineralium Deposita, 23, 86-95.

Clayton, R. N., \& Mayeda, T. K. (1963). The use of bromine pentafluoride in the extraction of oxygen from oxides and silicates for isotopic analysis. Geochimica et Cosmochimica Acta, 27, 43-52.

Clayton, R. N., O'Neil, J. R., \& Mayeda, T. K. (1972). Oxygen isotope exchange between quartz and water. Journal of Geophysical Research, 77, 3057-3067.

Davis, D. W., Lowenstein, T. K., \& Spencer, R. J. (1990). Melting behavior of fluid inclusions in laboratory-grown halite crystals in the systems $\mathrm{NaCl}-\mathrm{H}_{2} \mathrm{O}, \mathrm{NaCl}-\mathrm{KCl}-\mathrm{H}_{2} \mathrm{O}, \mathrm{NaCl}-\mathrm{MgCl}_{2}-\mathrm{H}_{2} \mathrm{O}$, and $\mathrm{NaCl}-\mathrm{CaCl}_{2}-$ $\mathrm{H}_{2} \mathrm{O}$. Geochimica et Cosmochimica Acta, 54, 591-601.

Dutta, P. K., \& Suttner, L. J. (1986). Alluvial sandstone composition and paleoclimate. II. Authigenic mineralogy. Journal of Sedimentary Petrology, 56, 346-358.

Fabre, C., Boiron, M. C., Dubessy, J., \& Moissette, A. (1999). Determination of ions in individual fluid inclusions by laser ablation optical emission spectroscopy: Development and applications to natural fluid inclusions. Joumal of Analytical Atomic Spectrometry, 14, 913-922.

Feng, X. H., Cui, H. T., Tang, K. L., \& Conkey, L. E. (1999). Tree-ring delta $\mathrm{D}$ as an indicator of Asian monsoon intensity. Quaternary Research, 51, 262-266.

Fontes, J. Ch. (1980). Environmental isotopes in groundwater hydrology. In P. Fritz \& J. Ch. Fontes, Handbook of environmental isotope geochemistry. The terrestrial environment (pp. 75-140). .

Fontes, J. Ch., \& Matray, J. M. (1993). Geochemistry and origin of formation brines from the Paris Basin, France. 1. Brines associated with Triassic salts. Chemical Geology, 109, 149-175.

Galindo, C., Tornos, F., Darbyshire, D. P. F., \& Casquet, C. (1994). The age and origin of the barite-fluorite $(\mathrm{Pb}-\mathrm{Zn})$ veins of the Sierra de Guadarrama (Spanish Central System, Spain): a radiogenic (Nd, Sr) and stable isotope study. Chemical Geology, 112, 351-364.

García, E., Vindel, E., \& López García, J. A. (1999a). Análisis de la geometría de la circulación hidrotermal en granitos mineralizados del área de San Rafael (Sistema Central Español). Reviews in Sociedad Geológica de España, 12, 369-376.

García, E., Vindel, E., \& López García, J. A. (1999b). Evolución de los fluidos asociados a la mineralización de As-(Ag) de Bustarviejo (Sistema Central): Estudio preliminar. Bolivian Sociedad Española de Mineralogía, 22, 49-50.

Gil, J., \& García, A. (1996). El Cretácico del borde meridional del Sistema Central: unidades litoestratigráficas y secuencias deposicionales. Estudios Geológicos, 52, 37-49.

Gleeson, S. A., Wilkinson, J. J., Boyce, A. J., Fallick, A. E., \& Stuart, F. M. (1999). On the occurrence and wider implications of anomalously low $\delta \mathrm{D}$ fluids in quartz veins, South Cornwall, England. Chemical Geology, 160, 161-173.

Gleeson, S. A., Grant, K., \& Roberts, S. (2000). Fluid inclusion $\delta$ D in quartz does not always indicate the source of palaeo-hydrothermal fluids. Journal of Conference Abstracts, 5 (2), 445.

Godfrey, J. D. (1962). The deuterium content of hidrous minerals from the East-Central Sierra Nevada and Yosemite National Park. Geochimica et Cosmochimica Acta, 26, 1215-1245.

Halliday, A. N., \& Mitchell, J. G. (1984). K-Ar ages of clay-size concentrates from the mineralization of the Pedroches Batholith, Spain, and evidence for Mesozoic hydrothermal activity associated with the break up of Pangaea. Earth and Planetary Science Letters, 68, 229-239.

Heijlen, W., Muchez, Ph., Banks, D., \& Nielsen, P. (2000). Origin and geochemical evolution of synsedimentary, syn- and post-tectonic high-salinity fluids at the Variscan thrust front in Belgium. Journal of Geochemical Exploration, 69-70, 149-152.

Holser, W. (1979). Trace elements and isotopes in evaporites. R. G. Burns. Marine Minerals, Reviews in mineralogy, 6, 295-346.

Horita, J., Friedman, T. J., Lazar, B., \& Holland, H. D. (1991). The composition of Permian seawater. Geochimica et Cosmochimica Acta, 55, 417-432.

Tbarrola, E., Villaseca, C., Vialette, Y., Fúster, J. M., Navidad, M., Peinado, M., \& Casquet, C. (1987). Dating of Hercynian granites in the Sierra de Guadarrama (Spanish Central System), Geología de los 
granitoides y roca asociadas del Macizo Hespérico. Madrid: Rueda pp. 377-383.

Kamber, B. S., Blenkinsop, T. G., Villa, I. M., \& Dahl, P. S. (1995). Proterozoic transpressive deformation in the Northern Marginal Zone, Limpopo Belt, Zimbabwe. Joumal of Geology, 103, 493-508.

Kesler, S. E., Appold, M. S., Martini, A. M., Walter, L. M., Huston, T. J., \& Kyle, J. R. (1995). Na-Cl-Br systematics of mineralizing brines in Mississippi Valley-type deposits. Geology, 23, 641-644.

Lodemann, M., Fritz, P., Wolf, M., Ivanovich, M., Hansen, B. T., \& Nolte, E. (1998). On the origin of saline fluids in the KTB (Continental Deep Drilling Project of Germany). Applied Geochemistry, 13, 653671.

Luckge, A., Doose-Rolinski, H., Khan, A. A., Schulz, H., \& Von Rad, U. (2001). Monsoonal variability in the northeastern Arabian Sea during the past 5000 years: Geochemical evidence from laminated sediments. Palaeogeography, Palaeoclimatology and Palaeoecology, 167, 273286.

MacDonald, A. J., \& Spooner, T. C. (1981). Calibration of a Linkam TH 600 programmable heating-cooling stage for microthermometric examination of fluid inclusions. Economic Geology, 76, 1248-1258.

Marfil, R., Delgado, A., Rossi, C., La Iglesia, A., \& Ramseyer, K. (2002). Origin and diagenetic evolution of kaolin minerals in reservoir sandstones and associated shales of the Jurassic and Cretaceous of the Salam Field, Western Desert (Egypt). The Clay Cement Special Publication, Intemational Association of Sedimentologists, in press.

Martín Crespo, T., López García, J. A., Banks, D., Vindel, E., \& García, E. (1999). Hydrothermal fluids in barren quartz veins (Spanish Central System). A comparison with $\mathrm{W}(\mathrm{Sn})$ and $\mathrm{F}(\mathrm{Ba})$ veins. Bolivian Sociedad Española de Mineralogía, 22, 83-94.

Mitchell, J. G., \& Halliday, A. N. (1976). Extent of Triassic/Jurassic hydrothermal ore deposits on the North Atlantic margins. Transactions of Institute of Mineral Metallurgy, B85, 159-161.

Moissette, A., Dubessy, J., Boiron, M. C., Fabre, C., Mauchien, P., \& Lacour, J. L. (1997). Laser ablation OES and its application to individual fluid inclusions analysis: State of the art. Proceedings of the XIV ECROFI, Nancy, 211-212.

Muchez, Ph., \& Sintubin, M. (1998). Contrasting origin of palaeofluids in a strike-slip fault system. Chemical Geology, 145, 105-114.

Muchez, Ph., Slobodnik, M., Viaene, W. A., \& Keppens, E. (1995). Geochimical constraints on the origin and migration of palaeofluids at the northern margin of the Variscan foreland, southern Belgium. Sedimentary Geology, 96, 191-200.

Munoz, M., Boyce, A. J., Courjault-Rade, P., Fallick, A. E., \& Tollon, F. (1994). Multi-stage fluid incursion in the Palaeozoic basement-hosted Saint-Salvy ore deposit (NW Montagne Noire, Southern France). Applied Geochemistry, 9, 609-626.

Munoz, M., Boyce, A. J., Courjault-Rade, P., Fallick, A. E., \& Tollon, F. (1999). Continental basinal origin of ore fluids from southwestern Massif central fluorite veins (Albigeois, France): evidence from fluid inclusion and stable isotope analyses. Applied Geochemistry, 14, 447458.

Naden, J. (1996). CalcicBrine: a Microsoft Excel 5.0 Add-in for calculating salinities from microthermometric data in the system $\mathrm{NaCl}-\mathrm{CaCl}_{2}-$ $\mathrm{H}_{2}$ O. Program and Abstracts PACROFI VI, Wisconsin, 1996, 97-98.

O'Connor, P. J., Högelsberger, H., Feely, M., \& Rex, D. C. (1993). Fluid inclusion studies, rare-earth element chemistry and age of hydrothermal fluorite mineralization in western Ireland-A link with continental rifting? Transactions of Institute of Mineral Metallurgy, B102, 141-148.

O'Reilly, C., Jenkin, G. R. T., Feely, M., Alderton, D. H. M., \& Fallick, A. E. (1997). A fluid inclusion and stable isotope study of $200 \mathrm{Ma}$ of fluid evolution in the Galway Granite, Connemara, Ireland. Contributions of Mineralogy and Petrology, 129, 120-142.

Pérez del Villar, L., Crespo, M. T., Pardillo, J., Pelayo, M., \& Galán, M. P. (1996a). U and Th series disequilibrium in the unaltered and hydrothermally altered granites from the El Berrocal site. Applied Radiation Isotopes, 47, 1115-1119.

Pérez del Villar, L., De la Cruz, B., Pardillo, J., Cózar, J. S., Pelayo, M.,
Marín, C., Rivas, P., Reyes, E., Caballero, E., Delgado, A., Núñez, R., Crespo, M. T., \& Galán, M. P. (1996b). Lithogeochemical characterization and evolutive model of the El Berrocal site: analogies with a HLRWR. Topical Report 2, El Berrocal project. Characterization and validation of natural radionuclide migration processes under real conditions on the fissured granitic environment, vol. 1. ENRESA pp. 302-487.

Reutel, Chr., Behr, H. J., Horn, E. E., \& Van den Kerkhof, A. M. (1994). The fluid research program of the Continental Deep Drilling Project KTB (Germany): I. Characteristics of fluid inclusions and their relationship with saline water and gases in crystalline rocks. PACROFI V, Cuernavaca, 1994, 80.

Rozanski, K., Araguás, L., \& Gonfiantini, R. (1993). Isotopic patterns in modern global precipitation. Climatic Change in Continental Isotopic Records, Geophysical Monograph, 78, 1-36.

Samson, I. M., \& Walker, R. T. (2000). Cryogenic raman spectroscopic studies in the system $\mathrm{NaCl}-\mathrm{CaCl}_{2}-\mathrm{H}_{2} \mathrm{O}$ and amplications for lowtemperature phase behaviour in aqueous fluid inclusions. Canadian Mineralogist, 38, 35-43.

Scherer, M. (1977). Preservation, alteration and multiple cementation of aragonite skeletons from the Cassian beds (U. Triassic, Southern Alps): Petrographic and geochemical evidence. Neues Jahrbuch fur Geologie und Palaontologie, 154, 213-262.

Shackleton, N. J., \& Kennett, J. (1975). Paleotemperature history of the Cenozoic and the initiation of the Antarctic glaciation: Oxygen and carbon isotope analyses in DSDP Sites 227, 279 and 281. Initial Reports of the Deep Sea Drilling Project, 29, 743-755.

Shepherd, T. J., Rankin, A. H., \& Alderton, D. H. M. (1985). A Practical Guide to Fluid Inclusion Studies, London: Blackie and Sons.

Spencer, R. J., Moller, N., \& Weare, J. H. (1990). The prediction of mineral solubilities in natural waters: A chemical equilibrium model for the $\mathrm{Na}-\mathrm{K}-\mathrm{Ca}-\mathrm{Mg}-\mathrm{Cl}-\mathrm{SO}_{4}-\mathrm{H}_{2} \mathrm{O}$ system at temperatures below $25^{\circ} \mathrm{C}$. Geochimica et Cosmochimica Acta, 54, 575-590.

Tornos, F., Casquet, C., Locutura, J., \& Collado, R. (1991). Fluid inclusion and geochemical evidence for fluid mixing in the genesis of $\mathrm{Ba}-\mathrm{F}(\mathrm{Pb}-$ $\mathrm{Zn}$ ) lodes of the Spanish Central System. Mineralogical Magazine, 55, 225-234.

Tornos, F., Delgado, A., Casquet, C., \& Galindo, C. (2000). 300 Million years of episodic hydrothermal activity: Stable isotope evidence from hydrothermal rocks of the Eastern Iberian Central System. Mineralium Deposita, 35, 551-569.

Utrilla, R., Ortí, F., Pueyo, J. J., \& Pierre, C. (1989). Stable isotope study of Mesozoic and Cenozoic evaporitic formations from Spain. European Union Geoscience, Strasbourg, 1, 335.

Utrilla, R., Pierre, C., Ortí, F., \& Pueyo, J. J. (1992). Oxygen and sulphur isotope composition as indicators of the origin of Mesozoic and Cenozoic evaporites from Spain. Chemical Geology, 102, 229-244.

Vennemann, T., \& Smith, H. (1990). The rate and temperature of reaction of $\mathrm{ClF}_{3}$ with silicate minerals and their relevance to oxygen isotope analysis. Chemical Geology, 86, 83-88.

Vialette, Y., Bellido, F., Fúster, J. M., \& Ibarrola, E. (1981). Datos geocronológicos sobre el granito de La Cabrera. Cuadernos Geología Ibérica, $7,327-338$.

Villa, I. M. (1998). Isotopic closure. Terra Nova, 10, 42-47.

Villaseca, C., Eugercios, L., Snelling, N. J., Huertas, M. J., \& Castellón, T. (1995). Nuevos datos geocronológicos ( $\mathrm{Rb}-\mathrm{Sr}, \mathrm{K}-\mathrm{Ar})$ de granitoides hercínicos de la Sierra de Guadarrama. Reviews in Sociedad Geológica de España, 8, 129-140.

Villaseca, C., Barbero, L., \& Rodgers, G. (1998). Crustal origin of Hercynian peraluminous granitic batholiths of Central Spain: Petrological, geochemical and isotopic ( $\mathrm{Sr}, \mathrm{Nd}$ ) constraints. Lithos, 43, 55-79.

Vindel, E., Lopez, J. A., Boiron, M. C., Cathelineau, M., \& Prieto, A. C. (1995). P-V-T-X-fO ${ }_{2}$ evolution from wolframite to sulphide depositional stages in intragranitic W-veins. An example from the Spanish Central System. European Joumal of Mineralogy, 7, 655-673.

Vindel, E., Lopez, J. A., Martín Crespo, T., \& García, E. (2000). Fluid 
evolution and hydrothermal processes of the Spanish Central System. Journal of Geochemical Exploration, 69-70, 359-362.

Weissert, H., \& Mohr, H. (1996). Late Jurassic climate and its impact on carbon cycling. Palaeogeography, Palaeoclimatology and Palaeoecology, 122, 27-43.

Wilkinson, J. J., Jenkin, G. R. T., Fallick, A. E., \& Foster, R. P. (1995). Oxygen and hydrogen isotopic evolution of Variscan crustal fluids, south Comwall, UK. Chemical Geology, 123, 239-254.

Yanatieva, O. K. (1946). Polytherms of solubility of salts in the tropic system $\mathrm{CaCl}_{2}-\mathrm{MgCl}_{2}-\mathrm{H}_{2} \mathrm{O}$ and $\mathrm{CaCl}_{2}-\mathrm{NaCl}-\mathrm{H}_{2} \mathrm{O}$. Journal of Applied Chemistry, 19, 709-722.

Yardley, B. W. D., Banks, D. A., Bottrell, S. H., \& Diamond, L. W. (1993). Post-metamorphic gold-quartz veins from N.W. Italy: The composition and origin of the ore fluid. Mineralogical Magazine, $57,407-422$.

Zhang, Y., \& Frantz, D. (1987). Determination of the homogenisation temperatures and densities of supercritical fluids in the system $\mathrm{NaCl}-$ $\mathrm{KCl}-\mathrm{CaCl}_{2}-\mathrm{H}_{2} \mathrm{O}$ using synthetic fluid inclusions. Chemical Geology, 64, 335-350.

Ziegler, A. M., Scotese, C. R., \& Barret, S. F. (1983). Mesozoic and Cenozoic paleogeographic maps, Tidal friction and the earth's rotation $I I$. Berlin: Springer pp. 240-252.

Zwart, E. W., \& Touret, J. L. R. (1994). Melting behaviour and composition of aqueous fluid inclusions in fluorite and calcite: Applications within the system $\mathrm{H}_{2} \mathrm{O}-\mathrm{CaCl}_{2}-\mathrm{NaCl}$. European Joumal of Mineralogy, 6 , $773-786$. 